\title{
Entrepreneurial Orientation in Government-Owned Bank: Do They Improve Competitive Advantage?
}

\author{
Maryono $^{1}$, Imam Ghozali ${ }^{1}$, Amie Kusumawardhani ${ }^{1}$, R. Mahelan Prabantarikso ${ }^{2}$ \& Firdaus Basbeth ${ }^{3}$ \\ ${ }^{1}$ Faculty of Economic and Business, Diponegoro University, Semarang, Indonesia \\ ${ }^{2}$ IBS Indonesia Banking School, Jakarta, Indonesia \\ ${ }^{3}$ IPMI International Business School, Jakarta, Indonesia \\ Correspondence: Imam Ghozali, Faculty of Economic and Business, Diponegoro University, Semarang, Indonesia.
}

Received: October 11, 2019

Accepted: December 23, 2019

Online Published: March 17, 2020

doi:10.5430/ijfr.v11n2p262

URL: https://doi.org/10.5430/ijfr.v11n2p262

\begin{abstract}
In Indonesia, housing finance is mainly raised from banks, with the government-owned housing bank (GOHB) BTN taking the largest share of the market. In constantly growing population need for new housing unit every year and increased number of competitors requires managers of government-owned housing bank to be able to develop their dynamic capabilities and adopt a more entrepreneurial orientation (EO). However, (GOHB) are typically being linked to organization that administratively influenced by government that impeding GOHB from being high performance organization driven by EO. Moreover, the dual goals of GOHB which are business and social goals makes the managers struggle to develop and adopt entrepreneurial orientation, since they have to set priorities and trade-off between those goals. The aims of this study is to investigate the role of entrepreneurial orientation (EO) in improving competitive advantage of government-owned housing bank, and fills a gap in the literature by linking entrepreneurial orientation to the theory of dynamic capabilities. This study explored the mediating effect of multi-dimensional EO which is: innovativeness, proactiveness, and risk taking in the relationship between dynamic capabilities (DC) and competitive advantage. The method of the study is a survey using area sampling and proportionate random sampling to collect data from 115 managers in 20 branches in island of Java, during the month of May to August, 2018 (cross-sectional method). The result shows a positive relationship between dynamic capabilities to innovativeness, proactiveness and risk taking. As expecting risk taking has no mediating effect to competitive advantage.
\end{abstract}

Keywords: dynamic capability, entrepreneurial orientation, competitive advantage, government-owned housing bank

\section{Introduction}

According to government data, Indonesia requires 800,000 units of new housing every year. In addition, the country needs to address a backlog of some 15 million units. The shortage of housing is particularly pressing in the low end of the market. The one million houses program was launched in mid-2015 which through this program the government aims to provide adequate housing facilities to low income families. Housing Finance Network (2017) reported that in Indonesia, housing finance is mainly raised from banks, with the government-owned Bank Tabungan Negara (BTN) taking the largest share of the market. The Indonesian housing finance industry has seen a considerable growth, shown by its ratio of mortgage debt to GDP has been growing from 2010 to 2017. However Indonesia's banking penetration (loan to GDP ratio was still the lowest among APAC countries represent opportunities for investor. An increasing number of banks in the banking sector have the potential to encourage businesses to be more competitive and improve the efficiency and health of banking. The finance sector is lead (41\%) by three states' owned bank and one private bank. Six other big banks run $16 \%$ of the market pie and 33\% run by other smaller commercial bank which in total include of 104 banks. Moreover, the threat of fintech that has been disrupting the traditional bank, is push bankers to improve banks' performance. To win the competition especially in providing housing loan for low income families, state-owned housing bank need to improve their competitive advantage and become more entrepreneurial driven organization and exploit their dynamic capability to be able to fill the housing backlog and leading competition with private housing banks. Rauch et al., (2009) suggested that firms which adopting entrepreneurial orientation (Rauch, Wiklund, Lumpkin, \& Frese) is likely to perform better 
than firm using conventional way because EO combine organizational resources and competences to contributes to strategic renewal and organizational transformation.

The phenomenon of an entrepreneurial orientation, has been a growing rate within the scholarly community (Covin and Lumpkin, 2011). Despite that EO have been studied in 30 years and the phrase had been mentioned in 3,946 journal articles since last eight years, EO research sometimes disconnected from their theoretical perspective such as institutional theory, agency theory, contingency theory or dynamic capabilities (J. G. Covin \& G. T. Lumpkin, 2011; D. Miller, 2011). Moreover, EO has inadequately explored as a dependent construct in the literatures (Sakari Soininen, Puumalainen, Sjögrén, Syrjä, \& Durst, 2013). The study that employed the multidimensional approach to the construct's and operate as dependent construct, is quite limited. This paper fills a gap in the literature by firstly providing a link to dynamic capabilities theories as crucial antecedents of EO, and secondly utilized multidimensional approach of EO and explored it as a dependent constructs. Therefore, this study also explains how the components of EO differ across their antecedent.

Our paper is organized as follows. First, we pull on noticeable theoretical arguments about our construct, and prior empirical evidence to derive hypotheses on conceptual model which denote the moderating role of business strategy in the relationships between DC and EO. The methods of analysis then described from two conceptual model with and without moderating effect of business strategy. Subsequently, we test our hypotheses using a partial least square structural equation modelling for those the conceptual model. The empirical results then presented and discussed with reference to their theoretical and practical implications, and finally limitations of our study and recommendations were pointed out for future research.

\section{Literature Review}

\subsection{Dynamic Capability (DC) and Competitive Advantage (CA)}

Despite the concept of dynamic capabilities have been analyzed from various perspectives and receives significant attention within the field of strategic management in more than a decade, many critical and unresolved issues still exist (Jurksiene \& Pundziene, 2016). The term "dynamic capability" then was perceived in different meaning, to (Barreto, 2010; Teece, Pisano, \& Shuen, 1997; Zollo \& Winter, 2002) it was defined as capabilities, whilst (Eisenhardt \& Martin, 2000) observed dynamic capabilities as specific strategic processes and routines (Barreto, 2010; Eisenhardt, Furr, \& Bingham, 2010; Eisenhardt \& Martin, 2000). To (Adner \& Helfat, 2003; Barreto, 2010) dynamic capabilities are identified as competencies, perceived as abilities (Barreto, 2010; Eisenhardt et al., 2010; Helfat \& Winter, 2011; Martin, 2011), and termed as capacities (Bingham \& Eisenhardt, 2008; Martin, 2011).

Initially, a dynamic capabilities concept was regarded as an extension of Barney (1991) recourse-based view (Schilke, 2014). RBV suggested that resources may include physical organizational resources, technological, human, capabilities and knowledge, which can used to gain competitive advantage. However according to (Eisenhardt \& Martin, 2000; Pisano, 2017; Teece et al., 1997), RBV alone often not enough to be used as a method to win competition and maintaining competitive advantage (CA) in fast unpredictable changing environments. Teece et al. (1997) considered dynamic capabilities to be a firm's ability to "integrate, build and reconfigure internal and external competencies to address rapidly changing environments" Teece et al. (1997) suggested dynamic capability (DC), as the management capability to spot difficulties, reconfigure resources, adapt new processes and organizational structures, to seize opportunities and systematically reach new set of resource arrangements in highly dynamic markets (Pisano, 2017; Teece et al., 1997). Thus, dynamic capability concerns with the reconfiguration or promote changes of existing recourses, creating new recourses (Helfat \& Peteraf, 2003; Schilke, 2014) to lead to competitive advantage.

The positive relationship between DC and CA has shown by a number of researcher empirically (Cleff, Lin, \& Walter, 2014; Schilke, 2014; Vanpoucke, Vereecke, \& Wetzels, 2014). SME dynamic capabilities have a positive impact on relative financial performance (Nedzinskas, Pundzienè, Buožiūtė-Rafanavičienè, \& Pilkienè, 2013). In a higher environmental change conditions, dynamic capabilities positively relates to competitive advantage through changing operational capabilities in consulting firms (Seyed Kalali \& Heidari, 2016). From the above explanation we posit:

H1: DC positively influences competitive advantage

\subsection{Dynamic Capability (DC) and Entrepreneurial Orientation}

Most researchers have cooperatively agreed on the understanding that EO is a behavioral model of entrepreneurship in a firm-level. The entrepreneurial orientation (Rauch et al.) emerges from an intentional strategic choice, where new business opportunities can be successfully undertaken (G. T. Lumpkin \& G. G. Dess, 1996). It originates from 
strategic management literature as strategic postures that explain a firm's behavior (Khandwalla, 1977; Mintzberg, 1973). The concept stems from the view that all organization fall somewhere along the low scale of conservative to high end level of entrepreneurial (J. G. Covin \& D. P. Slevin, 1989; Covin \& Slevin, 1991; D. Miller, 1983). D. Miller (1983) Conceptualized EO as the extent to which organizations are innovative, proactive, as well as risk-takers. Innovativeness refers to the inclination to pursue new products and services (Lumpkin \& Dess, 2001; Zahra \& Covin, 1995). Proactiveness entails the tendency to take the initiative and achieve a first mover advantage (Covin, Green, \& Slevin, 2006). Risk-taking refers to the propensity to invest in entrepreneurial initiatives with an uncertain outcome, as well as to operate in a leveraged manner (Lumpkin \& Dess, 1996). An entrepreneurially oriented firm actively innovates through new products and services, acts proactively in order to identify changing consumer needs, responds to competitors moves, undertakes risky ventures, and delegates responsibility to their employees for effective decision-making (Lumpkin \& Dess, 1996).

As it is relationship with firm capabilities and process, Wiklund and Shepherd (2005) explained that EO depends on the firms' internal resources: tangible and intangible assets work together with dynamic capabilities to stimulate EO. Specifically, their study highlighted the role of intangible resources in the development of dynamic capabilities and EO. Confirming to (Wiklund \& Shepherd, 2005) claimed, Jantunen (2015) stated that entrepreneurial firms create opportunities through their actions, and to be able to take advantage of the opportunities created, firms need to have capability to reconfigure their resources to convert the opportunities to competitive advantage. This is also in line with (Kreiser, Anderson, Marino, \& Kuratko, 2013) suggestion that EO is a strategic actions that exploit potentially valuable opportunities by using internal capabilities. Based on the above discussion, we hypothesized dynamic capability positively relate to EO, and since this study utilized EO as multidimensional construct, hence we explore the effect of DC to each dimension of EO. Therefore we hypothesized that

$\mathrm{H} 2$ : DC positively influences innovativeness

H3: DC positively influences proactiveness

H4: DC positive influences risk taking

\subsection{Entrepreneurial Orientation (Rauch et al.) and Competitive Advantage (CA)}

EO is a behavioral model of entrepreneurship in a firm-level that can influences strategic decisions, resource allocations and ability to seize more business opportunities to contributes to competitive advantage (Zahra, Nielsen, \& Bogner, 1999), hence it may be considered as intangible valuable assets and capabilities (Covin \& Wales, 2011; Rosenbusch, Rauch, \& Bausch, 2013). Some researcher considered EO as intangible valuable assets and capabilities, (Bakar \& Ahmad, 2010; Covin \& Wales, 2011; Rosenbusch et al., 2013), because it influences specific strategic decisions and resource allocations and allow firms to seize more business opportunities. On the other hand, Covin and Miller (2014) conceived EO as an organizational capability, which is a decision-making proclivity favoring entrepreneurial activities. Thus combination of organizational resources and competences enable EO contributes to organizational transformation and strategic renewal through creation and (Zahra et al., 1999). Rauch et al. (2009), stated that for firms adopting entrepreneurial orientation it is likely to perform better than companies that adopt conservative orientation. Firms with greater EO tend to seize more business opportunities (Rauch et al., 2009). Literature suggests that EO stimulated by dynamic capabilities that work on the firms' VRIN resources (Borch \& Madsen, 2007; Wiklund \& Shepherd, 2005). On the other hand, EO has been proven by number of researcher to influence performance (Al-Swidi \& Mahmood, 2011; T. Lumpkin \& G. Dess, 1996; Monteiro, Soares, \& Rua, 2017; Pratono \& Mahmood, 2015). A study by Mahmood and Hanafi (2013) established that EO positively relate to competitive advantage and firm performance in SME context. Based on the above discussion, we hypothesized EO positively relate to competitive advantage. We view EO as multidimensional construct, hence we explore the effect of each dimension of EO; innovativeness, proactiveness and risk taking positively relate to competitive advantage. Accordingly we hypothesized that

H5: Innovativeness positively influences competitive advantage

H6: Proactiveness positively influences competitive advantage

H7: Risk taking positively influences competitive advantage

\subsection{Mediating Role of Entrepreneurial Orientation}

As stated previously, firms with high level of EO actively innovates to responds to competitors moves, acts proactively in identifying changing consumer needs, and undertakes risk positively relate to CA (Lumpkin \& Dess, 1996), and DC has positive relation to EO and, thus EO is mediating the relationship between DC and CA. In this 
study, EO is viewed as multi-dimensional construct which consist of Innovation (INNO), proactiveness (PROA) and risk taking (RISK), accordingly the following hypothesis is formulated:

H8: innovativeness mediates the relationship between dynamic capability and competitive advantage

H9: proactiveness mediates the relationship between dynamic capability and competitive advantage

H10: risk-taking mediates the relationship between dynamic capability and competitive advantage

\section{Research Method}

This study utilized a cross-sectional mail survey to senior managers responsible in strategic decision making in state bank focus on housing loan, such as CEO, Board of Directors, and Branch Managers. In total, 120 managers and head branches were mailed out, and 73 usable responses were received for an effective response rate of $61 \%$. To test hypothesis and SmartPLS3 software bootstrapping report is employed to process the data.

\subsection{Measure}

There are basically two major conceptualizations of Entrepreneurial orientation construct (Covin \& Lumpkin, 2011; George \& Marino, 2011) unidimensional conceptualization is associated with (Covin \& Slevin, 1989; Miller \& Friesen, 1982) and multidimensional conceptualization is associated with (Lumpkin \& Dess, 1996). Entrepreneurial orientation is conceptualized as having anywhere from three to five dimensions, which may vary independently (Lumpkin \& Dess, 1996) and an organization could exhibit relatively high levels of one or more dimensions and, at the same time, relatively low levels of other dimensions (Lyon, Lumpkin, \& Dess, 2000). In our research, we focused on the three most commonly cited Entrepreneurial orientation dimensions: innovativeness, risk taking, and proactiveness. To measure dimensions of Entrepreneurial orientation, we used (Covin \& Slevin, 1989) nine-item 5-point scale Entrepreneurial orientation scale, which is intended to assess three components of firm-level Entrepreneurial orientation-innovativeness, risk taking, and proactiveness. This measurement scale has been used satisfactorily by a number of empirical papers (Green, Covin, \& Slevin, 2008).

To measure competitive advantage construct, we used the work of (Mahmood \& Hanafi, 2013). The three dimension of competitive advantage consist of: differentiated product, market responsiveness and information based service. Dynamic capabilities were measured according to the six dimension mentioned earlier, that is: sensing, learning, integrating, coordinating, and reconfiguring (Pavlou \& El Sawy, 2011). The study uses a questionnaire survey approach to collect data. The questionnaires used five-point Likert-style responses ranged from $1=$ "strongly disagree", through $3=$ "neutral" to 5 = "strongly agree".

\section{Result}

\subsection{Measurement Model Evaluation}

Evaluation of the moderator variable's measurement model includes internal consistency (Cronbach's alpha, composite reliability), convergent validity (indicator reliability, average variance extracted (Jing \& Avery) and discriminant validity (Cross Loadings, Fornell-Larcker criterion, HTMT) (Hair Jr et al., 2014). The result shows that the construct measure are reliable and valid, Cronbach's Alpha and composite reliability for all variable are above 0.7 respectively indicating internal consistency and reliability. For convergent validity yield an AVE of 0.705, providing support for convergent validity as shown in Table 1.

Table 1. Construct reliability and validity

\begin{tabular}{lllll}
\hline & $\begin{array}{l}\text { Cronbach's } \\
\text { Alpha }\end{array}$ & rho_A & $\begin{array}{l}\text { Composite } \\
\text { Reliability }\end{array}$ & $\begin{array}{l}\text { Average Variance } \\
\text { Extracted (AVE) }\end{array}$ \\
\hline Competitive Advantage & 0.774 & 0.774 & 0.870 & 0.790 \\
\hline Dynamic Capability & 0.800 & 0.801 & 0.862 & 0.756 \\
\hline INOV & 0.733 & 0.736 & 0.882 & 0.789 \\
\hline PROA & 0.716 & 0.718 & 0.875 & 0.779 \\
\hline RISK & 0.743 & 0.747 & 0.886 & 0.795 \\
\hline
\end{tabular}

For discriminant validity, cross loading report, and Fornell-Larcker shown that all criterion was fulfilled. The HTMT examination based on the average of heterotrait-heteromethod correlation as suggested by (Henseler, Ringle, \& 
Sarstedt, 2015), shown that the value is lower than 0.90 (at 95\% confident interval). Further we tested whether the HTMT values are significantly different from 1. The result of bootstrapping report on Confidence Interval Bias Corrected, showed that neither of the confidence interval includes the value 1 , therefore discriminant validity established for the model.

\subsection{Structural Model Evaluation}

To test the structural model, collinearity, path coefficient, coefficient of determination (R2 Value), effect size (f2), and blind folding predictive relevant $(\mathrm{Q} 2)$ was employed for theory development and explanation of prediction of the construct (Hair Jr, Hult, Ringle, \& Sarstedt, 2014). The evaluation of Collinearity was shown that All VIF value are below 5, thus predictor construct doesn't have collinearity problem. The coefficient of determination R2 for competitive advantage is 0.920 (large), the $\mathrm{f} 2$ effect size of dynamic capability on competitive advantage is 0.298 (medium), innovativeness, and proactiveness to competitive advantage is 0.446 (medium) and 0.532 (large), whilst for risk taking is 0.019 (small). On Blindfolding and Predictive Relevance (Q2), the resulting Q2 values with omission distance $\mathrm{D}=7$, for competitive advantage $\mathrm{Q} 2$ values $(0.588)$ which all values of construct are greater than 0 , indicate that the model has predictive relevance. Therefore, all criteria to evaluate the structural model has satisfied.

The strength of the relationship between dynamic capability and competitive advantage is shown by path coefficient (0.310) indicate a strong relationship as well as innovativeness and proactiveness to competitive advantage, however relationship of risk taking to competitive advantage has a weak relationship (0.060). Variable that affect the strongest total effect to competitive advantage is dynamic capability (0.898), indicate that the dimension of EO has mediating effect and causing high total indirect effect and direct effect. As can be seen in Figure 1.

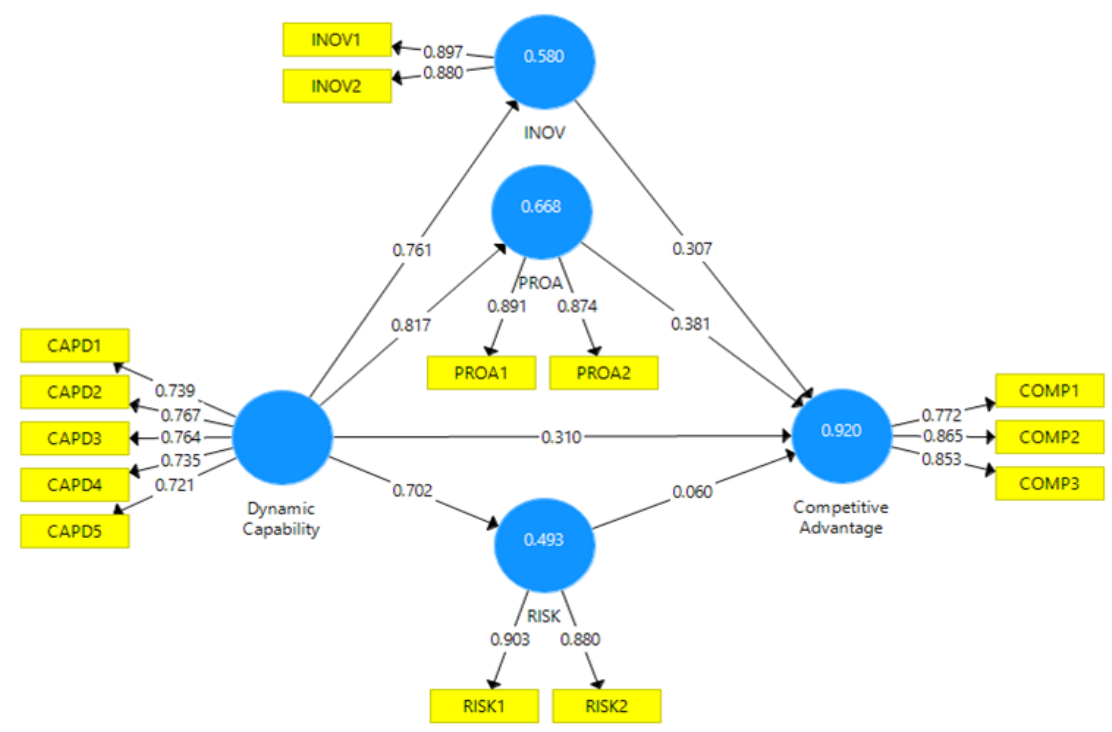

Figure 1. Research model

\subsection{Hypothesis Testing}

Based on the bootstrap resampling procedure with 5000 subsamples, the result of the hypothesis testing was summarized in Table 1. The result showed that DC has a strong positive impact to CA, INOV, PROA, and RISK, shown by high value of path coefficient $>0.7$ and $t$ value $>1.964 .3$ and $p$ value $<0.05$ with bootstrapping of $95 \%$ confident interval doesn't include the value 0 , indicate that Hypothesis 1 to 4 is supported. The strongest relationship is between DC and PROA (0.817) which is significant with t value 24.281 and $p$ values 0.000 . Innovativeness and proactiveness positively and significantly relate to competitive advantage, showed by the value of path coefficient $(0.307)$ and $(0.381)$, and significance at t-stats and p-value $(8.085,0.000)$, and $(8.120,0000)$ indicate that Hypothesis 5 and 6 is supported. However, the result shows Hypothesis 7 is not supported 
Table 2. Path coefficient, $\mathrm{t}$-values, $\mathrm{p}$-values and confidence intervals

\begin{tabular}{|c|c|c|c|c|c|c|}
\hline & \multirow{2}{*}{$\begin{array}{l}\text { Path } \\
\text { coefficient }\end{array}$} & \multirow{2}{*}{$\begin{array}{l}\mathrm{T} \\
\text { value }\end{array}$} & \multirow{2}{*}{$\begin{array}{l}\mathrm{P} \\
\text { Values }\end{array}$} & \multicolumn{2}{|c|}{$\begin{array}{l}\text { Confidence interval } \\
\text { bias corrected }\end{array}$} & \multirow{2}{*}{ Hypothesis } \\
\hline & & & & $2.5 \%$ & $97.5 \%$ & \\
\hline $\mathrm{DC} \rightarrow \mathrm{CA}$ & 0.310 & 5.646 & 0.000 & 0.204 & 0.417 & H1 supported \\
\hline $\mathrm{DC} \rightarrow \mathrm{INOV}$ & 0.761 & 21.262 & 0.000 & 0.677 & 0.821 & H2 supported \\
\hline $\mathrm{DC} \rightarrow \mathrm{PROA}$ & 0.817 & 24.281 & 0.000 & 0.734 & 0.870 & H3 supported \\
\hline $\mathrm{DC} \rightarrow \mathrm{RISK}$ & 0.702 & 15.928 & 0.000 & 0.595 & 0.774 & H4 supported \\
\hline $\mathrm{INOV} \rightarrow \mathrm{CA}$ & 0.307 & 8.085 & 0.000 & 0.229 & 0.377 & H5 supported \\
\hline $\mathrm{PROA} \rightarrow \mathrm{CA}$ & 0.381 & 8.120 & 0.000 & 0.285 & 0.470 & H6 supported \\
\hline RISK $\rightarrow$ CA & 0.060 & 1.406 & 0.160 & -0.021 & 0.146 & H7 not supported \\
\hline
\end{tabular}

Note: * Significant at 0.05(1-tailed)

Finally we tested the hypothesis of mediating role of innovativeness, proactivenss and risk taking. The specific indirect effect of the mediating variables can be seen in Table 3.

Table 3. Bootstrapping report for indirect and direct relationship

\begin{tabular}{|c|c|c|c|c|c|c|c|}
\hline Indirect relationship & $\begin{array}{l}\text { Original } \\
\text { Sample }\end{array}$ & $\begin{array}{l}\mathrm{T} \\
\text { Statistics }\end{array}$ & $\begin{array}{l}\mathrm{P} \\
\text { Values }\end{array}$ & $2.5 \%$ & $97.5 \%$ & $\begin{array}{l}\text { Total } \\
\text { effect }\end{array}$ & VAF \\
\hline $\begin{array}{l}\text { Dynamic Capability } \rightarrow \text { INOV } \rightarrow> \\
\text { Competitive Advantage }\end{array}$ & 0.234 & 8.520 & 0.000 & 0.180 & 0.287 & 0.544 & $43.01 \%$ \\
\hline $\begin{array}{l}\text { Dynamic Capability } \rightarrow \text { PROA } \rightarrow> \\
\text { Competitive Advantage }\end{array}$ & 0.311 & 7.632 & 0.000 & 0.233 & 0.394 & 0.621 & $50.08 \%$ \\
\hline $\begin{array}{l}\text { Dynamic Capability } \rightarrow \text { RISK }-> \\
\text { Competitive Advantage }\end{array}$ & 0.042 & 1.398 & 0.162 & -0.015 & 0.105 & 0.352 & \\
\hline
\end{tabular}

As can be seen from Table 2, the indirect relationship for both Innovativeness and Proactiveness are positive and significant with $\mathrm{t}$ value $>1.96$ and $\mathrm{p}$ value $<0.005$, and confidence interval bias corrected at $95 \%$ doesn't include 0 , therefore the indirect relationship is significant, indicate complementary mediating effect for both variables, and partially mediate the relationship between dynamic capability and competitive advantage with variance accounted for (VAF) innovativeness and proactiveness is $43.01 \%$ and $50.08 \%$. Therefore, Hypothesis 8 and 9 are supported. However, construct RISK has no mediating effect, since indirect relationship DC $\rightarrow$ RISK $\rightarrow$ CA is not significant with $\mathrm{t}$ value and pvalue $(1.398,0.162)$, and confidence interval bias corrected include 0 , therefore $\mathrm{H} 7$ is not supported.

\section{Discussion and Research Implication}

This study confirmed that dynamic capabilities have a positive effect to innovativeness and proactiveness, and both has significant relationship to competitive advantage. Dynamic capabilities therefore are a powerful antecedent for innovativeness, and proactiveness, and both construct complementary mediate the relationship between dynamic capability and competitive advantage of the firm. This analysis supports earlier argument that dynamic capability influence entrepreneurial orientation (Borch \& Madsen, 2007; Monteiro et al., 2017) and plays a critical part in endorsing firm competitive advantage (Ambrosini \& Bowman, 2009; Rosenbusch et al., 2013; Teece et al., 1997). Innovativeness and Proactiveness creates business opportunity and the dynamic capability manage and process it together with good strategy to deliver competitive advantage. The dimension of dynamic capabilities that has most impact to innovativeness, and proactiveness is the learning and integrating capabilities. With the large opportunity in the banking industry showing increasing rate, the risk in the banking industry is minimum with threat mostly came from foreign bank and other smaller competitor and fintech digital banking. Practical implication is that GOHB bank is expected to be more proactive in grabbing business opportunities at middle to high class segment market, and 
growing more innovation in low end market for example using digital banking, simplify business process, and co-innovate with their banking ecosystem. Whilst other dimension of EO which is risk taking has no mediating effect, shown by negative path coefficient in its relationship to competitive advantage. This could be explained that since the bank is owned by government and rules by layers of regulation and bureaucracy that pushed mangers to conduct business prudently. This study includes certain limitation firstly the date collected from the only GOHB which is BTN, thus open the opportunity to do comparative study with other private bank. Secondly the approach of data collection relies on single source responses from higher level of management to measure competitive advantage, and it was recommend to observe through multi sources data for instance from the perspective of employees and other stake holder.

\section{Conclusion}

The findings indicate that effect of dynamic capabilities, innovativeness, and proactiveness in the context of SOEs banking are essential for firms to improve their competitive advantage. However, the effect managerial attitude towards risk (risk taking) is positive but not significant influence the competitive advantage of the firm. More innovativeness and proactiveness mediate the relationship between dynamic capabilities to competitive advantage. This finding denotes that competitive advantage of a firm could be stimulated and facilitated through innovativeness and proactiveness activities in firms' level but not risk taking since risk taking is a managerial attitude toward risk in strategic decision making activities which is apparently influenced by the culture in this context is state bank focus on housing loan. This finding is important as it will give an impact to state housing bank operates in Indonesia that dynamic capabilities work well through innovativeness and proactiveness to increase firm's competitive advantage.

\section{References}

Adner, R., \& Helfat, C. E. (2003). Corporate effects and dynamic managerial capabilities. Strategic Management Journal, 24(10), 1011-1025. https://doi.org/10.1002/smj.331

Al-Swidi, A. K., \& Mahmood, R. (2011). How does organizational culture shape the relationship between entrepreneurial orientation and the organizational performance of banks?. European Journal of Social Sciences, 20(1), 28-46.

Ambrosini, V., \& Bowman, C. (2009). What are dynamic capabilities and are they a useful construct in strategic management?. International Journal of Management Reviews, $11(1), \quad 29-49$. https://doi.org/10.1111/j.1468-2370.2008.00251.x

Bakar, L. J. A., \& Ahmad, H. (2010). Assessing the relationship between firm resources and product innovation performance: A resource-based view. Business Process Management Journal, 16(3), 420-435. https://doi.org/10.1108/14637151011049430

Barney, J. (1991). Firm resources and sustained competitive advantage. Journal of Management, 17(1), 99-120. https://doi.org/10.1177/014920639101700108

Barreto, I. (2010). Dynamic capabilities: A review of past research and an agenda for the future. Journal of Management, 36(1), 256-280. https://doi.org/10.1177/0149206309350776

Bingham, C. B., \& Eisenhardt, K. M. (2008). Position, leverage and opportunity: a typology of strategic logics linking resources with competitive advantage. Managerial and Decision Economics, 29(2-3), 241-256. https://doi.org/10.1002/mde.1386

Borch, O. J., \& Madsen, E. L. (2007). Dynamic capabilities facilitating innovative strategies in SMEs. International Journal of Technoentrepreneurship, 1(1), 109-125. https://doi.org/10.1504/IJTE.2007.014731

Cleff, T., Lin, I. C., \& Walter, N. (2014). Can You Feel It? The Effect of Brand Experience on Brand Equity. IUP Journal of Brand Management, 11(2).

Covin, \& Slevin. (1989). Strategic management of small firms in hostile and benign environments. Strategic Management Journal, 10(1), 75-87. https://doi.org/10.1002/smj.4250100107

Covin, J. G., \& Lumpkin, G. T. (2011). Entrepreneurial orientation theory and research: Reflections on a needed construct. Entrepreneurship Theory and Practice, https://doi.org/10.1111/j.1540-6520.2011.00482.x

Covin, J. G., \& Miller, D. (2014). International entrepreneurial orientation: Conceptual considerations, research themes, measurement issues, and future research directions. Entrepreneurship Theory and Practice, 38(1), 11-44. https://doi.org/10.1111/etap. 12027 
Covin, J. G., \& Slevin, D. P. (1989). Strategic management of small firms in hostile and benign environments. Strategic Management Journal, 10(1), 75-87. https://doi.org/10.1002/smj.4250100107

Covin, J. G., \& Slevin, D. P. (1991). A conceptual model of entrepreneurship as firm behavior. Entrepreneurship Theory and Practice, 16(1), 7-26. https://doi.org/10.1177/104225879101600102

Covin, J. G., \& Wales, W. J. (2011). The measurement of entrepreneurial orientation. https://doi.org/10.1111/j.1540-6520.2010.00432.x

Covin, J. G., Green, K. M., \& Slevin, D. P. (2006). Strategic process effects on the entrepreneurial orientation-sales growth rate relationship. Entrepreneurship Theory and Practice, 30(1), 57-81. https://doi.org/10.1111/j.1540-6520.2006.00110.x

Eisenhardt, K. M., \& Martin, J. A. (2000). Dynamic capabilities: what are they?. Strategic management journal, $21(10-11)$,

1105-1121. https://doi.org/10.1002/1097-0266(200010/11)21:10/11<1105::AID-SMJ133>3.0.CO;2-E

Eisenhardt, K. M., Furr, N. R., \& Bingham, C. B. (2010). CROSSROADS-Microfoundations of performance: Balancing efficiency and flexibility in dynamic environments. Organization Science, 21(6), 1263-1273. https://doi.org/10.1287/orsc.1100.0564

George, \& Marino. (2011). The epistemology of entrepreneurial orientation: Conceptual formation, modeling, and operationalization. Entrepreneurship Theory and Practice, 35(5), 989-1024. https://doi.org/10.1111/j.1540-6520.2011.00455.x

Green, K. M., Covin, J. G., \& Slevin, D. P. (2008). Exploring the relationship between strategic reactiveness and entrepreneurial orientation: The role of structure-style fit. Journal of Business Venturing, 23(3), 356-383. https://doi.org/10.1016/j.jbusvent.2007.01.002

Hair, J. F. Jr., Hult, G. T. M., Ringle, C., \& Sarstedt, M. (2014). A primer on partial least squares structural equation modeling (PLS-SEM). Sage Publications.

Helfat, C. E., \& Peteraf, M. A. (2003). The dynamic resource-based view: Capability lifecycles. Strategic Management Journal, 24(10), 997-1010. https://doi.org/10.1002/smj.332

Helfat, C. E., \& Winter, S. G. (2011). Untangling dynamic and operational capabilities: Strategy for the (N) ever-changing world. Strategic Management Journal, 32(11), 1243-1250. https://doi.org/10.1002/smj.955

Henseler, J., Ringle, C. M., \& Sarstedt, M. (2015). A new criterion for assessing discriminant validity in variance-based structural equation modeling. Journal of the Academy of Marketing Science, 43(1), 115-135. https://doi.org/10.1007/s11747-014-0403-8

Jing, F. F., \& Avery, G. C. (2016). Missing Links In Understanding The Relationship Between Leadership And Organizational Performance. The International Business \& Economics Research Journal (Online), 15(3), 107. https://doi.org/10.19030/iber.v15i3.9675

Jurksiene, L., \& Pundziene, A. (2016). The relationship between dynamic capabilities and firm competitive advantage: The mediating role of organizational ambidexterity. European Business Review, 28(4), 431-448. https://doi.org/10.1108/EBR-09-2015-0088

Khandwalla, P. N. (1977). The design of organizations.

Lumpkin, \& Dess. (1996). Clarifying the entrepreneurial orientation construct and linking it to performance. Academy of Management Review, 21(1), 135-172. https://doi.org/10.5465/amr.1996.9602161568

Lumpkin, \& Dess. (2001). Linking two dimensions of entrepreneurial orientation to firm performance: The moderating role of environment and industry life cycle. Journal of Business Venturing, 16(5), 429-451. https://doi.org/10.1016/S0883-9026(00)00048-3

Lumpkin, G. T., \& Dess, G. G. (1996). Clarifying the entrepreneurial orientation construct and linking it to performance. Academy of Management Review, 21(1), 135-172. https://doi.org/10.5465/amr.1996.9602161568

Lyon, Lumpkin, \& Dess. (2000). Enhancing entrepreneurial orientation research: Operationalizing and measuring a key strategic decision making process. Journal of Management, 26(5), 1055-1085.

Mahmood, R., \& Hanafi, N. (2013). Entrepreneurial orientation and business performance of women-owned small and medium enterprises in Malaysia: Competitive advantage as a mediator. International Journal of Business and Social Science, 4(1). 
Martin, J. A. (2011). Dynamic managerial capabilities and the multibusiness team: The role of episodic teams in executive leadership groups. Organization Science, 22(1), 118-140. https://doi.org/10.1287/orsc.1090.0515

Miller, \& Friesen. (1982). Innovation in conservative and entrepreneurial firms: Two models of strategic momentum. Strategic Management Journal, 3(1), 1-25. https://doi.org/10.1002/smj.4250030102

Miller, D. (1983). The correlates of entrepreneurship in three types of firms. Management Science, 29(7), 770-791. https://doi.org/10.1287/mnsc.29.7.770

Miller, D. (2011). Miller (1983) revisited: A reflection on EO research and some suggestions for the future. Entrepreneurship Theory and Practice, 35(5), 873-894. https://doi.org/10.1111/j.1540-6520.2011.00457.x

Mintzberg, H. (1973). Strategy-making in three modes. California Management Review, 16(2), 44-53. https://doi.org/10.2307/41164491

Monteiro, A. P., Soares, A. M., \& Rua, O. L. (2017). Linking intangible resources and export performance: The role of entrepreneurial orientation and dynamic capabilities. Baltic Journal of Management, 12(3), 329-347.

Nedzinskas, Š., Pundzienè, A., Buožiūtè-Rafanavičienè, S., \& Pilkienė, M. (2013). The impact of dynamic capabilities on SME performance in a volatile environment as moderated by organizational inertia. Baltic Journal of Management, 8(4), 376-396. https://doi.org/10.1108/BJM-01-2013-0003

Pavlou, P. A., \& El Sawy, O. A. (2011). Understanding the elusive black box of dynamic capabilities. Decision Sciences, 42(1), 239-273. https://doi.org/10.1111/j.1540-5915.2010.00287.x

Pisano, G. P. (2017). Toward a prescriptive theory of dynamic capabilities: connecting strategic choice, learning, and competition. Industrial and Corporate Change, 26(5), 747-762. https://doi.org/10.1093/icc/dtx026

Pratono, A. H., \& Mahmood, R. (2015). Mediating effect of marketing capability and reward philosophy in the relationship between entrepreneurial orientation and firm performance. Journal of Global Entrepreneurship Research, 5(1), 5. https://doi.org/10.1186/s40497-015-0023-x

Rauch, A., Wiklund, J., Lumpkin, G. T., \& Frese, M. (2009). Entrepreneurial orientation and business performance: An assessment of past research and suggestions for the future. Entrepreneurship Theory and Practice, 33(3), 761-787. https://doi.org/10.1111/j.1540-6520.2009.00308.x

Rosenbusch, N., Rauch, A., \& Bausch, A. (2013). The mediating role of entrepreneurial orientation in the task environment-performance relationship: A meta-analysis. Journal of Management, 39(3), 633-659.

Sakari Soininen, J., Puumalainen, K., Sjögrén, H., Syrjä, P., \& Durst, S. (2013). Entrepreneurial orientation in small firms-values-attitudes-behavior approach. International Journal of Entrepreneurial Behavior \& Research, 19(6), 611-632. https://doi.org/10.1108/IJEBR-10-2012-0106

Schilke, O. (2014). On the contingent value of dynamic capabilities for competitive advantage: The nonlinear moderating effect of environmental dynamism. Strategic Management Journal, 35(2), 179-203.

Seyed Kalali, N., \& Heidari, A. (2016). How was competitive advantage sustained in management consultancies during change: The role of dynamic capabilities. Journal of Organizational Change Management, 29(5), 661-685. https://doi.org/10.1108/JOCM-10-2015-0188

Teece, D. J., Pisano, G., \& Shuen, A. (1997). Dynamic capabilities and strategic management. Strategic Management Journal, 18(7), 509-533.

Vanpoucke, E., Vereecke, A., \& Wetzels, M. (2014). Developing supplier integration capabilities for sustainable competitive advantage: A dynamic capabilities approach. Journal of Operations Management, 32(7-8), 446-461.

Wiklund, J., \& Shepherd, D. (2005). Entrepreneurial orientation and small business performance: a configurational approach. Journal of Business Venturing, 20(1), 71-91. https://doi.org/10.1016/j.jbusvent.2004.01.001

Zahra, S. A., \& Covin, J. G. (1995). Contextual influences on the corporate entrepreneurship-performance relationship: A longitudinal analysis. Journal of Business Venturing, 10(1), 43-58.

Zahra, S. A., Nielsen, A. P., \& Bogner, W. C. (1999). Corporate entrepreneurship, knowledge, and competence development. Entrepreneurship Theory and Practice, 23(3), 169-189.

Zollo, M., \& Winter, S. G. (2002). Deliberate learning and the evolution of dynamic capabilities. Organization Science, 13(3), 339-351. https://doi.org/10.1287/orsc.13.3.339.2780 